\title{
Detection of Ehrlichia canis in bone marrow aspirates of experimentally infected dogs
}

\author{
Detecção de Ehrlichia canis em aspirados de medula óssea de cães experimentalmente infectados
}

\author{
Simone Magela Moreira ${ }^{1}$ Rosângela Machado² Lygia Friche Passos $^{3}$
}

\begin{abstract}
The present work describes the detection of infected cells in the bone marrow aspirates of dogs experimentally infected with a Brazilian isolate of Ehrlichia canis. Dogs were monitored twice a day by clinical evaluation and peripheral blood smear examination. Every three days, blood samples were collected for cell counts. Weekly, aspirates from the bone marrow were examined and serum samples were tested by IFAT. The clinical signs observed were fever, pallid membranes, lymphadenopathy, serous nasal secretions, and pronounced weight loss. Hematological alterations included normocytic normochromic anemia, decrease of neutrophils and lymphocytes, and thrombocytopenia. Few E. canis infected cells were seen in blood smears. However, stages of E. canis were visualized in bone marrow aspirates 15 days post infection.
\end{abstract}

Key words: Ehrlichia canis, diagnosis, bone marrow puncture, dogs.

\section{RESUMO}

O presente trabalho descreve a detecção de células infectadas em aspirados de medula óssea de cães experimentalmente infectados com uma amostra brasileira de Ehrlichia canis. Os cães foram monitorados duas vezes por dia através de avaliação clínica e exames de esfregaços de sangue periférico. A cada três dias, amostras de sangue foram coletadas para contagem celular. Semanalmente foram feitas punções de medula óssea para exame microscópico direto do material aspirado e coleta de sangue para exames sorológicos através da reação de imunofluorescência indireta. Os sinais clínicos observados foram febre, membranas pálidas, linfadenopatias, secreções nasais serosas e acentuada perda de peso. As alterações hematológicas incluíram anemia normocítica normocrômica, redução de neutrófilos e linfócitos e trombocitopenia. Poucas células infectadas com $\boldsymbol{E}$. canis foram observadas em esfregaços sanguíneos, entretanto várias formas de desenvolvimento de E.canis foram visualizadas em aspirados de medula óssea 15 dias após a infecção.

Palavras-chave: Ehrlichia canis, diagnóstico, punção de medula óssea, cães.

Canine ehrlichiosis, also known as Tropical pancytopenia, is a fatal hemorrhagic syndrome, characterized by thrombocytopenia, epistaxe and progressive pancytopenia (HUXSOLL et al., 1970). The causal agent, Ehrlichia canis, is a rickettsia transmitted by the tick Rhipicephalus sanguineus, that multiplies inside mononuclear leukocytes, affecting several organs, such as the spleen, lymphonodes and liver (WOLDEHIWET \& RISTIC, 1993).

During the acute phase, the parasite can be detected in the cytoplasm of circulating monocytes for a short period of time. The

${ }^{1}$ Departamento de Medicina Veterinária Preventiva, Universidade Federal de Minas Gerais (UFMG), Belo Horizonte, MG, Brazil. ${ }^{2}$ Departamento de Patologia Veterinária, Universidade Estadual Paulista, Jaboticabal, SP, Brazil.

${ }^{3}$ Departamento de Medicina Veterinária Preventiva, UFMG, Brasil. Corresponding author. Departamento de Medicina Veterinária Preventiva, Escola de Veterinária, Universidade Federal de Minas Gerais. CP 567, 30123-970, Belo Horizonte, Brazil. Phone: +55 31 34992092. Fax: +55 31 34992080. Mailing address: lygia@dedalus.lcc.ufmg.br 
surviving animals remain infected, but the parasite cannot be seen in blood smears, which is still the routine diagnostic method for detection of hemoparasites.

Cases of ehrlichiosis in dogs have increased considerable over the last years (MOREIRA et al., 2003) and there is a need for more sensitive and specific tests to enable clinicians implementing early treatment.

In the present study, we evaluated clinically and by laboratory tests two mongrel dogs that had been experimentally inoculated with $5 \mathrm{ml}$ of cryopreserved blood infected with a Brazilian isolate of Ehrlichia canis (Jaboticabal strain). The E. canis strain was first isolated from a naturally infected dog and was frozen in liquid nitrogen at the Veterinary Teaching Hospital, UNESP, Jaboticabal, SP, Brazil (unpublished data).

The dogs were monitored daily by corporal temperature and peripheral blood smears, and every two days by hematological parameters and blood cell counts (erythrocytes, leukocytes and platelets). One of the dogs was also monitored weekly by direct examination of bone marrow aspirates. Blood smears and smears made from bone marrow aspirates were stained with Giemsa and examined by optical microscopy. Serum sample were obtained from the two animals before the experimental inoculation and 15 days after infection to evaluate humoral responses. These samples were tested for specific IgG response to $\boldsymbol{E}$. canis by IFAT (Indirect Fluorescent Antibody test) using a commercial kit (MegaScreen FLOREHRLICHIA c. $\left.{ }^{\circledR}\right)$. The two dogs were seronegative prior to infection.

The first clinical signs were detected 15 days after infection (PI), when the animals presented hyperthermia (mean temperature $40^{\circ} \mathrm{C}$ ), oculus-nasal discharge and weight loss. The hematological alterations included normocytic normochromic anemia during the first week PI. In the third week PI, the total number neutrophils decreased, with a decrease of segmented neutrophils and lymphocytes, in addition to a thrombocytopenia.

Single morula were detected in peripheral blood smears on day 11 (animal 1) and on day 13 (animal 2) (Figure 1), while several E. canis inclusions were seen in the cytoplasm of monoblasts and mature monocytes in bone marrow aspirates on day $15 \mathrm{PI}$ (Figure 2)

Inclusions of $\boldsymbol{E}$. canis infecting bone marrow of dogs have been previously reported

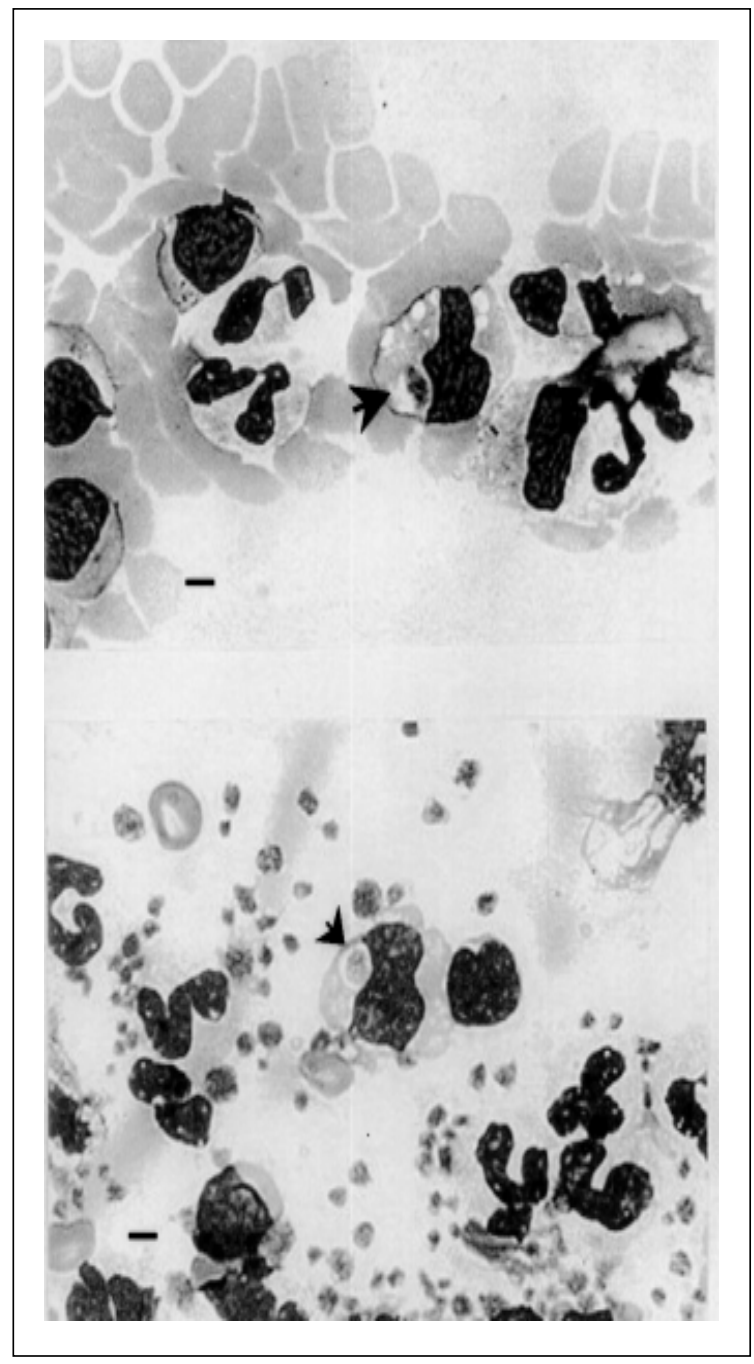

Figure 1 - Microphotography of peripheral blood smears of a dog showing Ehrlichia canis morulae (arrows) inside monocytes (Giemsa staining, 1,000 x). Bar $2.5 \mathrm{~mm}$

associated to a super acute disease with nonregenerative anemia, in which infected leukocytes were rare (Meinkoth et al., 1989). At that time, the infected dogs showed positive antibody titers for $\boldsymbol{E}$. canis detected at 1:64 dilutions.

One of the problems associated with treatment of clinical cases of canine erlichiosis is related to difficulties in detecting morula in peripheral blood smears. Therefore, detection of parasites in other sites and in other biological fluids would represent improvements for the diagnosis and evaluation of recovery of clinically affected dogs.

It was concluded that Ehrlichia canis develops a parasitism in the bone marrow that allows 


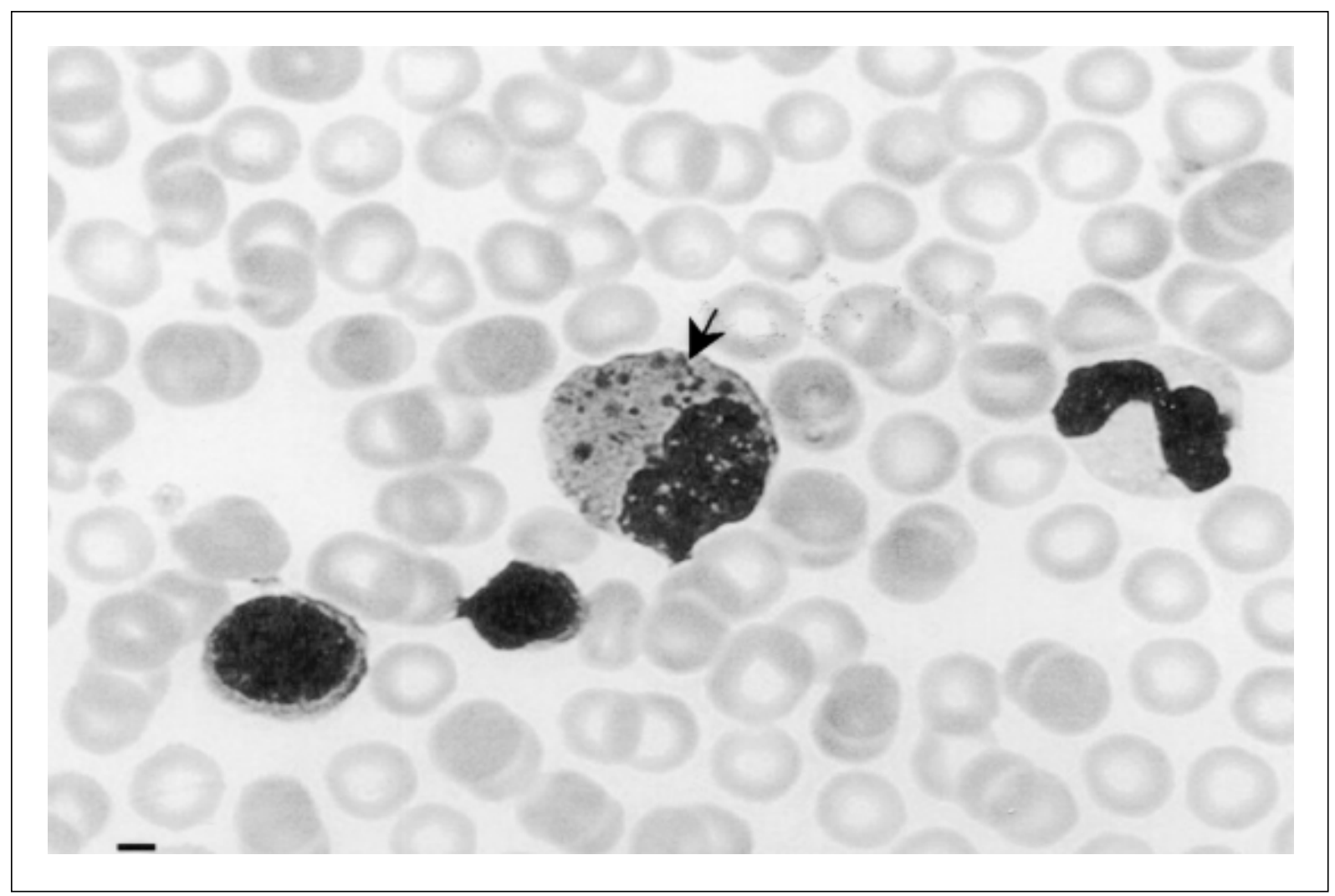

Figure 2 - Microphotography of a bone marrow aspirate of a dog infected with Ehrlichia canis showing inclusions in the cell cytoplasm (arrow) (Giemsa staining 1,000 x). Bar $2.5 \mathrm{~mm}$.

detection of inclusions during the acute phase, suggesting that the direct examination of bone marrow aspirates can be useful for easier identification of $\boldsymbol{E}$. canis infections in dogs even when no peripheral intracellular morulae are detectable.

This study (protocol n. 035/03) is in agreement with the Ethical Principles in Animal Experimentation, adopted by the Ethics Committee on Animal Experimentation (CETEA/UFMG) and was approved in December 2003.

\section{REFERENCES}

HUXSOLL, D.L. et al. Tropical canine pancytopenia. J Am Vet Med Assoc, v.157, n.11, p.1627-1632, 1970.

MEINKOTH, J.H. et al. Ehrlichiosis in a dog with seizures and non regenerative anemia. J Am Vet Med Assoc, v.195, n.12, p.1754-1755, 1989 .

MOREIRA, S.M. et al. Retrospective study (1998-2001) on canine ehrlichiosis in Belo Horizonte, M.G, Brazil. Arq Bras Med Vet Zootec, v.55, n.2, p.141-147, 2003.

WOLDEHIWET, Z.; RISTIC, M. Rickettsial and chlamydial diseases of domestic animals. Oxford : Pergamon, 1993. 427p. 